\title{
Teachers' Morale and Academic Performance of Secondary School Students in South West, Nigeria
}

\author{
Johnson Oluwole Ehineni \\ Faculty of Education, Adekunle Ajasin University, Akungba Akoko, Nigeria \\ Email address: \\ oluwoleehineni@yahoo.com \\ To cite this article: \\ Johnson Oluwole Ehineni. Teachers' Morale and Academic Performance of Secondary School Students in South West, Nigeria. Teacher \\ Education and Curriculum Studies. Vol. 2, No. 5, 2017, pp. 68-73. doi: 10.11648/j.tecs.20170205.12
}

Received: March 4, 2017; Accepted: April 13, 2017; Published: September 30, 2017

\begin{abstract}
The poor performance of students in Senior Secondary School Certificate Examination in recent time, particularly in Southwest Nigeria, appears to be discouraging. This study sought to investigate the effectiveness of teachers' morale on secondary school students' academic performance in South West, Nigeria. A questionnaire and a proforma were used for data collection. Public Secondary School teachers and students in South-West Nigeria formed the population for the study. The sample for the study comprised 375 teachers and 9375 students. Multistage stratified random sampling technique was used to choose the sample. Findings showed that teachers' morale made significant contribution to the prediction of students' academic performance. It accounted for $58.9 \%$ of the total variance in students' academic performance. In the same vein, all the indices of teachers' morale individually made significant contribution to the prediction of students' academic performance, with teachers' salary as the best predictor. Teachers' salary alone accounted for $47.4 \%$ of the total variance in students' academic performance, while teachers' workload was the least predictor with $3.8 \%$ contribution of the variance. There is a significant relationship between teachers' morale and students' academic performance $(r=0.49, p<0.05)$. While the paper concluded that students' performance is influenced by teachers' morale, it therefore recommended that policies that will enhance teachers' morale such as improved teachers' allowance should be put in place.
\end{abstract}

Keywords: Teachers' Morale, Academic Performance, Workload, Teacher’s Rapport

\section{Introduction}

Education is the most potent instrument of change in the intellectual and social outlook of any society. In Nigeria, as well as other countries of the world, education is a tool for socio-economic and political development (Valentine, 2003). This is further enunciated in the National Policy on Education (Federal Government of Nigeria, 2004) which stated that education will continue to be highly rated in the National Development Plans. However, for quality education to be attained, there is need for teachers and students to be alive to their responsibilities of teaching and learning in schools, especially in secondary schools. Teachers are important instruments in teaching and learning, they are also the pivot on which the educational process hang and teachers play a major role in the whims and caprices of the educational system, they can influence the teaching-learning outcome either positively or negatively because they determine the quality of instructional delivery and also influence quality education when it comes to implementation of the curriculum and educational policies. They are to be considered when addressing issues such as quality assurance, quality delivery (teaching), quality context and quality learning outcome (Onacha, 2002). For teachers to be effective and functional in this regard, they must have high morale.

The term 'morale' as opined by Danesty (2004) is recognized as powerful force and vital ingredient in the success of any human endeavour. Idiaghi (2004) defines it as "an individual liking more aspect of his work than dislike". Ofoegbu (2004) opines that it is a function of the difference between a person's preference for a task and his actual experience on the task. The author posited further that the less discrepancy, the greater the satisfaction, it is often believed that there will always be poor performance of students in all educational organization if teachers are not motivated. Therefore, it may be posited that the educational goals and objectives in the National Policy of Education may not be achieved if teachers are not motivated. Additionally, 
"student academic performance" in this study refers to the students' performance in English and Mathematics in Senior Secondary School Certificate Examination (SSCE) conducted by West African Examination Council (WAEC).

Adelabu (2005) as cited in Salifu and Agbenyega (2003), opined that the relationship between employee satisfactions and extrinsic factors, such as pay and allowance ascertained that satisfaction level varies directly with a sense of distributive justice which exists among the various employees. Workers morale towards achieving the objective of the organization, especially in the school setting, is tied to the environmental situation of the school and the management disposition towards workers' welfare. It is a conventional statement that there will always be poor performance of students in all educational organizations, if teachers are not motivated. Therefore, the educational goals and objectives in the National policy on education may not be achieved unless teachers are motivated. For teachers to do the work effectively, they have to be motivated since motivation enhances performance (Famade 2003).

Ibukun (2001) asserted that teacher's morale is a product of the teacher's set of needs; goals, derived values, experiences and expectations. In Nigerian secondary schools, teachers complained about their poor remuneration, transportation problems, inadequate motivation and shortage of staff among others. These militate against the growth of secondary education in the country. Students also complained about the inability of teachers to perform their duties. For instance, the students claimed that some teachers come to school once or twice a week while some live far away from their schools, hence, they either come late or fail to show up for their teaching; this happen often in schools in the rural areas. This lack of commitment on the part of teachers accounts for the inability of the teachers to cover vital areas of the syllabus. In secondary schools, especially when it is located in commercial cities, students complain that teachers often abandon their class work for a more profitable or profit making ventures. Such teachers only turn round to give assignments to cover up their inefficiency.

Akinsolu (2010) opined that it is a pity that teachers, whose primary occupation is to see to the total development of the child, physically, morally, spiritually and intellectually are rated as second class citizens. In recent times, one of the educational issues which have greatly aroused the interest of Nigerians is the extent to which teachers who constitute a large percentage of the working population are dissatisfied with their job (Babatola, 1992). Some sociologists and psychologists who have worked on the concept of teachers' morale indicated that teachers' morale is linked to the amount of their (teachers) enthusiasm about their job at a particular time (Johnsrued \& Rosser 2002)

Furthermore, there are two main facts of teachers' morale or job satisfaction. These are Intrinsic, which is internal and materialistic in nature. Contributing to the debate on teachers' morale, Ronen (2006) found that the intrinsic aspects of teachers' morale are better predictors of turnover than the extrinsic aspects. He also suggested that the tendency to stay in or leave an organization has common causes which are not accounted for by the level of satisfaction with the job. Morse (2004) in a study on the relationship between employees' job satisfaction and extrinsic factors such as pay and allowances stated that satisfaction levels vary directly with a sense of distributive justice which exists among the various employees. In other words, the denial of what the organizational members deem to be just and fair treatment concerning issues of importance to them is inevitably associated with lower levels of satisfaction.

Ronen, Tzur, \& Yaari (2006) in a study on morale, found a positive relationship between job satisfaction and seniority. Using a "U-shaped" curve to illustrate his point, he observed that satisfaction curve rises for new employees. This rise, he opined could be as a result of novelty and initial expectation. Employees who held a job for 2-5 years reported less satisfaction while employees who held the job for six years or more reported higher level of job satisfaction. In order to achieve the goals and aspiration of students' academic performance, the relationship between the school head and the subordinates (teachers) should be cordial, such conducive work environment includes autonomous, paternal, familiar and close climate. The availability of both human and nonhuman resources in any organization could influence the working conditions of the system hence increasing or decreasing productivity.

From observation, it is arguable that teachers' morale could influence academic performance of students. Omotosho (2006) argued that teachers' morale is one of the most significant factors that determine the educational height attained by each student. According to him, teachers' morale has the magic touch of raising the academic performance of students. Teachers can work to any length if they are well motivated. In the finding of Adeyemi (2008), the major source of educational inequality in secondary schools is the differences in the leadership style of head teachers and the motivational level of other staff in the school. It can intuitively be argued then that these issues may determine to certain extent the academic performance of students in the various secondary schools in Nigeria especially in the south west of the country.

I therefore note that if teachers' morale is enhanced, it is likely the students perform better academically but if otherwise, it may 'lead to less performance. This is because morale has two educational implications. First, it improves school services and makes them worthy of public respect. Secondly, enthusiastic teachers communicate their satisfaction and approval not only on students, but also parents and public. Good teachers are valuable asset to any school system. When teachers are provided with what they expect both monetarily and non-monetarily, the beneficiaries would not only be the teachers but the students and the community at large also. Consequent upon this background, the researcher investigated if there will be any relationship between teachers' morale and academic performance of secondary schools students in South West Nigeria. 


\section{Methodology}

The methodology reveals the theoretical and analytical framework, research design, population, sample and sample instrument.

\subsection{Theory of Motivation}

Herzberg as quoted by Linda (2010) explained that his research focused on the job satisfaction and motivation of engineers and accountants in Pittsburgh. Despite being a contentious study which has been criticized on methodological grounds, it is generally regarded as seminal and has drawn considerable attention from other researchers in the occupational psychology field. Feinstern (2000) revealed that in order to increase individual's satisfaction level, employees should be given advancement opportunities. Similarly changes in organizational variables such as pay scales, employee input in policy development, and work environment could then be made in an effort to increase organizational commitment and overall outcome. Safety, relation to work and success are followed by intergroup relation. Baah and Amoako (2011) described that the motivational factors (the nature of work, the sense of achievement from their work, the recognition, the responsibility that is granted to them, and opportunities for personal growth and advancement) helps employees to find their worth with respect to value given to them by organization. Further, this can increase motivational level of employees which will ultimately raise internal happiness of employees and that the internal happiness will cause satisfaction. Volkwein and Zhou (2003) found that organizational, environmental, and personal characteristics proved to be less influential than features such as teamwork, job security, and interpersonal relationship. They concluded that "overall satisfaction is the product of a complex balance of many ingredients".

From the analysis of his research findings, Herzberg formulated a theory which he called his motivation-hygiene theory, or, as it is also known, the two factor theory. His findings revealed two distinct sets of factors: one set which motivates, or satisfies, employees, and one set which may demotivate or create dissatisfaction. According to him, five features of work which motivate people or which are capable of providing job satisfaction are: achievement; recognition (for achievement); the work itself; responsibility; and advancement. Herzberg refers to these as motivation factors, and they all share the distinction of being factors that are intrinsic to the work. Those features that he identified as capable of non-motivating or creating dissatisfaction are labelled hygiene factors and are all extrinsic to the work. They include salary; supervision; interpersonal relations; working conditions; policy and administration. The essential point of Herzberg's theory is that hygiene factors are not capable of motivating or satisfying people, even though they may be sources of dissatisfaction. Herzberg contends that removing hygiene factors that are creating dissatisfaction does not indeed, and cannot - create job satisfaction because hygiene factors are incapable of doing so (except, as he points out, in the cases of a minority of individuals who are 'hygiene seekers'). So, for example, if employees are dissatisfied with, or de-motivated by, the salary they receive, giving them a pay rise will not motivate or satisfy them, it will merely ensure that they are not dissatisfied with their pay.

Herzberg likened a pay rise to 'a shot in the arm', which may offer a temporary boost, but whose effects are shortlived. According to him, removing sources of dissatisfaction does not ensure job satisfaction: only the intrinsic factors which the five motivation factors are able to do that: At the root of all human behaviours is motivation and motivation has meant many things over the years. In general, it refers to the process or factors (motives) that influence people to act. Psychologists view motivation as the process of (1) arousing behaviour (2) sustaining behaviour in progress and (3) channeling behaviour into a specific course. Motives induce the self (or will) to act and so result in behaviour. Banalson (1964) as cited in Ajayi and Ayodele (2002) opined that motivation is an inner state that energizes and activates individual towards a goal, Wiwharick (1987) cited in Ajayi and Ayodele (2002) described motivation as an instigator to action.

\subsection{Research Design}

The descriptive research design of the survey type and expost facto designs were adopted for this study. The Teachers' Morale Questionnaire (TMQ) was used to elicit information from the teachers while a Proforma was also designed to gather data on Students' Academic Performance (SAP). Information obtained from (TMQ) and the (SAP) Student Academic Performance proforma were used to describe the existing phenomenon (Teachers' Morale and Students Academic Performance).

\subsection{Population}

The population of this study comprised all the public secondary school teachers and students in the South West Nigeria comprising Oyo, Ondo, Ogun, Osun, Ekiti and Lagos States. As at the time of this study (year 2016), there were 4,297 registered public secondary schools, 60,533 teachers and 1,704,152 students as cited in National Bureau of Statistics, Social Statistics in Nigeria, Federal Republic of Nigeria, 2010.

\subsection{Sample and Sampling Technique}

A total number of 375 teachers and 9375 students were used for this study. The multi-stage random sampling technique was used in selecting the sample for the study. The Multi-stage Random Sampling Technique involved selecting subjects from the population in stages. The first stage involved stratifying the six states into three zones Lagos/Ogun, Osun/Oyo and Ondo/Ekiti. Second stage involved randomly selecting one state from each zone (three States out of the six existing states for the study). The third 
comprised a random selection of 5 Local Government Areas from each of the 3 States randomly selected. The fourth stage involved random selection of 5 schools in each of the Local Government Areas selected. At the end, this amounted to 25 schools in each State and 75 schools from the 3 States. The final stage involved random selection of 5 teachers and 125 students from each of the schools selected (1:25 that is the ratio is a teacher to 25 students).

\subsection{Research Instrument}

The data for this study were collected through the use of a questionnaire titled Teachers Morale Questionnaire (TMQ). The TMQ comprised two sections. Section A contained items on personal data that is designed to elicit background information on the teachers. Section B contained 40 statements meant to elicit information on the 8 indices of teachers' morale are: Rapport with the Principals, Teachers' Salary, Rapport among Teachers, Teachers Workload, Teachers Status, Community support for education, School facilities and services, and Community pressures. Teachers were asked to respond to the 40 statements on a 4-likert scale, $\mathrm{SA}=4, \mathrm{~A}=3, \mathrm{D}=2$, and $\mathrm{SD}=1$. The maximum score a teacher could score on this morale scale is 160 while the minimum score is 40 . The proforma was designed to collect data on students' academic performance in the 2 major subjects (English and mathematics) for one year (2014). By implication, a teacher is to 25 students. The cumulative grade points of these 25 students mark the students' academic performance of such a teacher. In recording the grade point for students, WAEC stanine scale was reversed (that is A1 = 9 points, B2 is 8 points, ... F9 $=1$ point.

\subsection{Analytical Technique}

The data collected after scoring were subjected to both descriptive and inferential statistics. The scoring patterns are stated below: Teacher Morale Questionnaire (TMQ) was a 4, Likert scale format, where 4 was awarded for Strongly Agree responses, 3 for Agree response, 2 for Disagree response and 1 for Strongly Disagree response.

For Students Academic Performance (SAP) WASSCE stanine scale was reversed such that:

$\begin{array}{ll}\text { WAEC Scale } & \text { WAEC Reverse Scale } \\ \text { A1 } & \text { was awarded 9 } \\ \text { B2 } & \text { was awarded } 8 \\ \text { B3 } & \text { was awarded 7 } \\ \text { C4 } & \text { was awarded 6 } \\ \text { C5 } & \text { was awarded 5 } \\ \text { C6 } & \text { was awarded 4 } \\ \text { D7 } & \text { was awarded 3 }\end{array}$

D8 F9 was awarded 2 was awarded 1

The descriptive aspects of the study were analyzed using frequency counts, means and percentage scores. The preliminary task that was performed involved classifying Teachers morale into two discrete units.

a. Those with High morale and

b. Those with Low morale.

To determine this grouping, the mean of responses of the respondents in the different secondary schools according to the groupings of each sub-scale of teachers' morale indices was obtained. After the preliminary computation, those responses that had a mean considered to be low morale are those with below 3.5 aggregate while those with 3.5 and above were considered to have high morale. The mean for the two groups indicated that:

A. Teachers with high morale was good i.e 72\% (3.62)

B. Teachers with middle i.e. $60 \%(3.5)$

C. Teachers with low morale was only fair i.e $59.75 \%$ (2. 99)

Multiple regressions was used to test Hypothesis 1, t-test statistics was used to test Hypotheses 2, 3, 4, 6, and 7. Pearson's product moment Correlation was used to test Hypothesis 5. All the hypotheses were tested at 0.05 level of significance.

\section{Results and Discussion}

The results are presented in terms of research questions that were formulated to guide the study and the results that were found out from the study.

Research Question One: What is the level of secondary school teachers' morale in South-West, Nigeria?

Table 1. Teachers Morale Percentage in the Different States.

\begin{tabular}{lll}
\hline Teachers States & Morale No. of Teachers & $\begin{array}{l}\text { Percentage of Teachers } \\
\text { Morale }\end{array}$ \\
\hline Lagos & 125 & 63.0 \\
Ondo & 125 & 60.8 \\
Osun & 125 & 56.8 \\
Total & 375 & 180.6 \\
\hline
\end{tabular}

The level of teachers morale in secondary schools in South West Nigeria is reveal in Table 1, of which Lagos State had the highest percentage of $63 \%$ academic performance followed by Ondo State with $60.8 \%$ academic performance. While Osun State had the lowest $56.8 \%$ academic performance. Generally, the teachers' morale does not seem high enough.

Research Question Two: What is the level of secondary school students' academic performance in South-West, Nigeria?

Table 2. Teachers' Classification by Salary Grade Level and Morale in South-West Senior Secondary Schools.

\begin{tabular}{|c|c|c|c|c|c|c|c|}
\hline \multirow{2}{*}{ Salary Grade Level } & \multirow{2}{*}{ Freq. } & \multicolumn{2}{|l|}{ Urban } & \multirow{2}{*}{ Freq. } & \multicolumn{2}{|l|}{ Rural } & \multirow{2}{*}{ Total \% } \\
\hline & & \% High Morale & \% Lower Morale & & \% High Morale & $\%$ Lower Morale & \\
\hline $07-10$ & 30 & 22 & 78 & 35 & 41 & 59 & 100 \\
\hline $12-14$ & 79 & 39 & 61 & 78 & 70 & 30 & 100 \\
\hline $15-16$ & 75 & 61 & 39 & 78 & 57 & 43 & 100 \\
\hline Total & 184 & & & 191 & & & \\
\hline
\end{tabular}


A cursory look at teachers' salary grade level and morale, revealed a trend of $22 \%$ of teachers on salary grade level 07 to 10 with high morale, while $78 \%$ had low morale in urban Senior Secondary Schools. But $41 \%$ recorded high morale and $59 \%$ low morale in rural schools.

Table 3. Sub-scale of Teachers' Morale Indices and Corresponding Mean of Students' Academic Performance.

\begin{tabular}{lll}
\hline Morale Indices & Frequency & $\begin{array}{l}\text { Mean Academic } \\
\text { Performance of } \\
\text { Students }\end{array}$ \\
\hline High rapport with principals & 310 & 139.80 \\
Low rapport with principals & 65 & 25.9 \\
High salary & 185 & 152.80 \\
Low salary & 190 & 114.79 \\
High rapport among teachers & 312 & 136.42 \\
Low rapport among teachers & 63 & 116.04 \\
Teachers with heavy workload & 188 & 129.23 \\
Teaches with fewer workload & 187 & 140.95 \\
High status & 292 & 140.28 \\
Low status & 83 & 109.84 \\
High community support for education & 299 & 139.60 \\
Low community support for education & 76 & 109.70 \\
High school facilities & 201 & 150.59 \\
Low school facilities & 174 & 113.85 \\
High community pressure & 248 & 141.67 \\
Low community pressure & 127 & 117.66 \\
\hline
\end{tabular}

From Table 3, the number of teachers with high rapport with principal was 310 , while teachers with low rapport were 65. The mean academic performance of students taught by teachers with high rapport with principal was 139.80 but the mean academic performance of students taught by teachers with low rapport with principals was 25.9. The mean academic performance of the students taught by teachers with high rapport with the principals out performed students taught by the teachers with low morale with principals.

In the same vein, the total number of teachers with high salary was 185 while the total number of teachers with low salary was 190 . The mean academic performance of students taught by teachers with high salary was 152.80 , while the mean academic performance of students taught by teachers with low salary was 114.79. Students taught by teachers with high salary performed more than the students taught by teachers with low salary.

A descriptive analysis of the sub-scale of teachers' morale is also depicted in table 4 .

Table 4. Mean Responses of Teachers on Eight Sub-Scales of Morale.

\begin{tabular}{llll}
\hline Morale Indices & Freq & Mean & SD \\
\hline Teachers' rapport with principal & 375 & 14.33 & 2.50 \\
Teachers' salary & 375 & 12.56 & 3.60 \\
Rapport among teachers & 375 & 15.25 & 2.25 \\
Teachers' workload & 375 & 11.10 & 3.31 \\
Teachers' status & 375 & 13.16 & 3.17 \\
Community support for Education & 375 & 13.79 & 3.04 \\
School facilities \& services & 375 & 12.16 & 3.27 \\
Community pressure & 375 & 11.89 & 3.26 \\
\hline
\end{tabular}

From table 4, the mean responses of teachers to the eight sub-scales of morale indices ranges between 11.10 to 15.25 with rapport among teachers' having high mean while teachers' workload have the lowest mean. This shows that teachers' workload does not affect the morale of teachers. However, factors such as teachers' rapport with principal and tecahers' salary are significant predictors of the morale of teachers. In other words, if these significant factors are addressed, the morale of teachers may increase significantly.

\section{Conclusion}

The study examined the extent to which teachers' morale influence students' academic performance in South-West Nigeria. An attempt was made to identify, describe and explain factors which may have related teachers' morale to students' academic performance. The result revealed that all the indices of teachers morale (i.e. community pressure, teachers workload, community support, rapport with other teachers, salary, teacher rapport with the principal, teachers status and school facility jointly accounted for $58.9 \%$ of the total variable in students' academic performance. The study further revealed that negative correlation exists between teachers' workload and students' academic performance and other indices of teachers' morale.

The study also indicated that all the indices of teachers' morale made significant relative influence to student academic performance. Teachers' salary made the greatest influence as it accounted for $47.4 \%$ of teachers' variable in academic performance. It showed that significant difference exists in the performance of students from teachers with high and low morale with principals in favour of teachers with high rapport with principals. The study revealed clearly that there is a difference in the performance of students taught by teachers of high salary and the student taught by teachers of low salary.

\section{Recommendations}

Teachers' morale is a significant element in improving performance especially in public secondary schools that has continued to perform below average in national examinations. In view of the findings and conclusion from this study a number of recommendations were suggested to ensure high morale of secondary school teachers in our public secondary schools in south west Nigeria. School administrators and policy planners have lots of role to play in order to enhance teacher's morale and students' academic performance. The under listed are what could be done to boost teachers' morale and improve tremendously student academic performance in our public secondary schools.

1. There is need to put in place policy that will enhance teachers' morale in all our public secondary schools so that there will be high academic performance of our students.

2. Since teachers in Lagos State have the highest morale in the South West Nigeria, the remaining states should emulate Lagos by putting special packages in place that 
will boost the morale of their teachers.

3. Ensure that there is good rapport among teachers in order to ensure crises free environment to promote academic performance of the students.

4. Equal attention should be given to schools in rural and urban environment to address the problems of their teachers' morale.

5. Ensure that teachers are involved in the decision making of the school to enhance students' academic performance.

6. Ensure that teachers are exposed to periodic seminar/workshops to make them update their knowledge in order to boost academic performance of the students.

7. Ensure that teachers' salary and allowance are paid as at when due in order to make them live comfortably and promote high academic performance of the students.

8. Ensure that there is cordial relationship between the teacher and the community where they teach so that they can offer the best for the students of the community.

9. Ensure that the school environment is friendly to teaching and learning to enhance students' academic performance.

10. Enough qualified teachers should be employed to teach both Science, Arts and Commercial subjects in public secondary school for better academic performance of students.

The findings of the study have far reaching significance for teachers' morale and students' academic performance in South West of Nigeria public secondary schools which is of great concern. Immediate attention is required on the part of the stake holders to improve the present state of teachers' morale in public secondary schools in the state which will invariably bring in better students' academic performance. The finding of this study revealed that there is an urgent need for improvement in the condition of service for teachers, provision of physical and materials resources as well as facilities in public secondary schools in order to improve students' academic performance, most especially in the senior school certificate examination (WAEC, SSCE).

\section{References}

[1] Adeyemi, T. O (2008), Predicting student's performance in Senior Secondary School Certificate Examination (SSSCE) Social Science Journal, 3 (1); 26-36.

[2] Ajayi, A. I. \& Ayodele, J. B. (2002). Fundamentals of educational Management. Ado-Ekiti: Greenline Publishers. 155 pp. 5.
[3] Akinsolu, A. O. (2001). Teachers and students academic performance in Nigerian secondary schools: Implication for planning. Florida Journal of Educational Administration and Policy, 3(2), 86-103.

[4] Danesty, A. H. (2004) Psychological determinants of academic performance and vocational learning of students with disabilities in Oyo State. Unpublished Ph. D Thesis, University of Ibadan.

[5] Famade, A. O. (2003) Educational Management. An Introduction Text. Pumak Nigeria Limited.

[6] Herzberg, F. (1968) One more time, how do you motivate employees. Harvard Business Review 46: 53-62.

[7] Ibukun W. O. (2002) Towards Performance of Teachers in Ondo State: Vision, Mission and Philosophy of Government on Education. In Taiwo, E. A. \& Esaipe Y. (Eds) Skills Improvement Programme from Effective Performance of Teachers in Nigeria Schools (pp 1 - 13) Ondo, NIEPA Printing Press.

[8] Idiaghi, J. E. (2004): Relationship between Education Facilities, Teacher Qualification School Location and Academic Performance of Students in Secondary School in Delta State. (Unpublished Ph. D. Dissertation), Delta State University Abraka.

[9] Johnsrud, L., and Rosser, V. J. (2002). Faculty members' morale and their intention to leave: A multilevel explanation, The Journal of Higher Education, 73 (4), 518-542.

[10] Linda, S et al. (2010) Employee satisfaction with meetings: A contemporary facet of job satisfaction. Human Resource Management 49 (2), 149-172.

[11] Ofoegbu, F. I. (2004). Teacher Motivation: A factor for Classroom Effectiveness and School Improvement in Nigeria. Gale Group. Retrieved June 15, 2010.

[12] Omotoso, S. A. (2006). Perception of headteachers' leadership styles by the teachers in Ondo State secondary schools. Unpublished, Ph. D Thesis, University of Ibadan, Nigeria.

[13] Onacha, C. O. (2002) Quality assurance in teacher education. In National Teachers' Institute (NTI) Teachers education in Nigeria. Past, present and future proceedings of the first Teachers' summit, February 2002 Kaduna: National Teachers' Institute.

[14] Ronen, J., Tzur, J., \& Yaari, V. L. (2006). The Effect of Directors' Equity Incentive, on Earnings Management. Journal of Accounting and Public Policy, 25, 359 - 389.

[15] Salifu, I., \& Agbenyega, J. S. (2013). Teacher Motivation and Identity formation issues affecting professional practice. MIER Journal of Educational Studies, Trends and Practices, 3 (1), $58-74$.

[16] Valentine, O. (2003). Affordability of needs through adequate pay. Boston: Little Brown and Company. 